\title{
Tainted earth: Smelters, public health, and the environment
}

\section{Citation}

Lanier-Christensen, Colleen. 2014. "Tainted earth: Smelters, public health, and the environment." Global Public Health 10 (2): 275-277. doi:10.1080/17441692.2014.986160. http:// dx.doi.org/10.1080/17441692.2014.986160.

\section{Published Version}

doi:10.1080/17441692.2014.986160

\section{Permanent link}

http://nrs.harvard.edu/urn-3:HUL.InstRepos:14065413

\section{Terms of Use}

This article was downloaded from Harvard University's DASH repository, and is made available under the terms and conditions applicable to Other Posted Material, as set forth at http:// nrs.harvard.edu/urn-3:HUL.InstRepos:dash.current.terms-of-use\#LAA

\section{Share Your Story}

The Harvard community has made this article openly available.

Please share how this access benefits you. Submit a story.

\section{Accessibility}




\section{BOOK REVIEW}

Tainted earth: Smelters, public health, and the environment, by Marianne Sullivan, New Brunswick, NJ, Rutgers University Press, 2014, 256 pp., US\$28.95 (paperback), ISBN 9780813562780

In Tainted Earth, Marianne Sullivan examines the impact of non-ferrous smelting pollution in three US communities, investigating how the smelting industry successfully delayed pollution control measures for nearly a century. Smelting, the process of extracting metals from ore, played an important (and lucrative) role in US manufacturing. The process releases impurities such as lead and arsenic, which can be released through smokestacks and contaminate surrounding environments. Confronted with evidence of smelters' toxic outputs, the profiled companies responded by controlling research, hiding information and mounting public relations campaigns to discredit their opposition and confuse the public. Focusing on the controversies surrounding three facilities in Tacoma, Washington; El Paso, Texas; and Kellogg, Idaho, Sullivan offers an engaging comparative study firmly grounded in historical context. Based on meticulous, well-documented research, Sullivan's narrative is of great relevance for a number of reasons.

First, Sullivan demonstrates that public health crises precipitated by smelting operations were not inevitable. Indeed, many foresaw the health consequences, yet none heeded the warnings. Sullivan establishes that the toxic effects of lead, arsenic and copper were well known not just in the medical and public health communities, but by the companies themselves. For example, in 1985, the Washington Supreme Court found that ASARCO (owner/operator of Tacoma and El Paso smelters) had known 'for decades' that their smelters emitted toxic metals (p. 145). Despite such knowledge, ASARCO and other smelting companies continued to make business decisions that prioritised financial success over public health. Ultimately, the health of countless children and adults living and working near the smelters was sacrificed due to preventable public health crises that resulted from ineffective research apparatuses, reluctance to invest in pollution controls and sympathetic regulatory regimes.

Second, Tainted Earth illuminates the consequences of the retreat of public health over the twentieth century, despite expanding environmental awareness and regulations. The public often views the 1970s as a time of environmental successes, but it was also a period dominated by corporate consolidation and a discourse of personal responsibility for health and disease. As public health increasingly was characterised as a scientific endeavour - dedicated to conducting good science, rather than effecting social change public health professionals shrunk from advocacy efforts to address the fundamental causes of unhealthful environments, which would have entailed challenging powerful corporate interests (Fairchild, Rosner, Colgrove, Bayer, \& Fried, 2010). In Tacoma, state health officials were sceptical that air pollution posed a health threat and were loath to oppose corporate interests. Instead, officials focused on individuals' contributions to air pollution (e.g., automotive emissions, fireplace smoke), despite their miniscule volume compared to smelter emissions. 
Similarly, the federal government failed to intervene in state pollution control. In the first half of the twentieth century, government officials lacked the expertise to challenge industry claims, but even as they gained significant expertise and regulatory powers in the second half of the century, they were 'reluctant to antagonize industry' (p. 51). By the 1960 s, the US smelting industry was in decline and reticent to invest in pollution controls for facilities with limited remaining lifespans. Industry leaders succeeded in keeping ageing facilities in operation by arguing that proposed environmental regulations (themselves based on inadequate science) were prohibitively expensive. In so doing, smelting companies furthered the key industrial narrative that placed jobs and health in opposition and framed environmental regulations as unwarranted impediments to economic growth. Regulators deferred to these industry narratives and delayed action such that none of the three smelters were forced to comply with federal pollution standards while in operation (all three smelters closed between 1981 and 1985).

Third, Tainted Earth adds to a growing body of literature based on documents uncovered in discovery processes of legal proceedings. Courtroom discovery often unearths previously confidential internal documents, which can be invaluable in understanding what corporations knew about the health impacts of their products and production practices. For example, through these documents, we learn that in 1970, Bunker Hill's vice-president for environmental affairs acknowledged internally, 'our emissions have destroyed most of the natural vegetation in the [Kellogg area]' (p. 81). In 1972, ASARCO tested soil from vacant lots and children's play areas near the Tacoma smelter, confirming significant lead and arsenic contamination that caused company officials 'some concern'. However, unsure what to do to address the issue and wary of bad publicity, the official was "inclined to let the "sleeping dog lie" absent inquiry from regulatory authorities (p. 124).

This unique use of sources enables Sullivan to reconstruct negotiations to define the health threat posed by smelter pollution. She finds that the smelting companies knew that their emissions were hazardous and deliberately manipulated studies to obscure this, even going as far as controlling the research process in order to produce more favourable results. In one study of children's blood lead levels surrounding Bunker Hill, Sullivan documents significant design flaws and a lapse of medical ethics: investigators appear to have selectively screened out children with the most severe health issues and failed to systematically monitor and follow up on children with elevated blood lead levels. While scrutinising the evidence available, Sullivan reminds us that many internal industry documents remain inaccessible, including those relevant to the health crises that she discusses. She demonstrates the importance of court records to public understanding of health controversies and the need for public access to these documents.

Fourth, Tainted Earth highlights the public health impacts of an understudied industrial process and its contaminants. Sullivan points out that smelters spurred some of the earliest pollution disputes and are often cited in environmental textbooks. Even so, the controversies around the public health impacts of smelting pollution have been given little in-depth consideration; existing investigations rarely focus on the lived experience of people in affected communities. Sullivan provides a thorough account of the controversies in these three communities, drawing heavily on the expertise and experiences of those figures central to these crises.

Sullivan's investigation is further notable because the contaminants she studies - lead, arsenic and copper - go beyond only lead, which has so thoroughly captured the attention of the public health community. Particular chemical threats often arouse the passion of health and environmental advocates; some contaminants thus receive far more research 
and regulatory scrutiny than others that may pose a similar threat. In part for this reason, early research on toxins in smelter pollution focused heavily on lead. Consequently, other contaminants such as arsenic were often overlooked. This persisted even when some scientists warned that other contaminants posed 'a more severe environmental health problem' than lead (p. 138), and the National Academy of Science described evidence of arsenic's carcinogenicity as 'strong' (p. 139). A lack of attention to arsenic precipitated a dearth of comprehensive studies in Tacoma. This attention deficit constituted a key barrier to regulatory action in Tacoma, where arsenic was indeed the major environmental contaminant.

Ultimately, Sullivan shows that despite extensive knowledge of the community health hazards posed by smelting pollution, none of these smelters were ever required to meet local or national emissions standards. As a result, the health of these three communities was sacrificed. For public health professionals, Tainted Earth illustrates the consequences of deferring to industry-sponsored science and of placing the burden of proof on citizens and regulators to produce 'convincing evidence' (p. 113) of health effects before taking regulatory action to protect public health.

Sullivan weaves compelling stories of communities where children's health was irreversibly damaged by heavy metal pollution following smelting industry efforts to downplay and obfuscate the risks of pollution, and efforts to stave off environmental regulation. Given the important subject matter and Sullivan's well-written and engaging narrative, Tainted Earth will appeal to students and professionals across a variety of fields, including public health, history of science, toxicology, geography and environmental policy. The text will also interest public health professionals grappling with the question of why policies intended to ameliorate health conditions can be unevenly implemented and thwarted by local actors with substantial interests in perpetuating the status quo.

\section{Reference}

Fairchild, A. L., Rosner, D., Colgrove, J., Bayer, R., \& Fried, L. P. (2010). The exodus of public health. What history can tell us about the future. American Journal of Public Health, 100(1), 54-63. doi:10.2105/AJPH.2009.163956

Colleen Lanier-Christensen Department of History of Science, Harvard University, Cambridge, MA, USA colleenlanier@fas.harvard.edu 